than bacteria are not covered. There is also a large amount of practical information on the purification, electron microscopy, and restriction mapping of plasmid DNA, and on the use of plasmids in gene cloning and sequencing. Transposable elements are covered also.

This book does not appear to be aimed specifically at one group of scientists. From the point of view of readers of the Journal of Medical Genetics, the lack of a chapter on the medical significance of plasmids-for example, their role in the spread of antibiotic resistance - is disappointing. Readers who are interested in the genetic engineering applications will find much of interest, but would probably do better with one of the more specialised texts on this subject. Therefore, the book seems to fall between two or three stools.

The presentation and style of the book are both good, with plenty of figures, tables, and references. The practical procedures are generally described in enough detail to be useful. Overall, although all of the individual articles are worthwhile, the book as a whole does not have an obvious appeal.

Duncan Shaw

\section{The Biology of Idiotypes}

Edited by M I Greene and A Nisonoff. (Pp 507; figures + tables. \$59.50.) New York: Plenum Press. 1984.

In the first chapter of the book The Biology of Idiotypes E A Kabat describes an experiment: “. . . immunisation with an anti-idiotypic antibody (antibody 2) induces the formation of immunoglobulins bearing idiotypes (antibody 3 ) some of which may have combining sites specific for the antigen which produced the original idiotypic antibody (antibody 1) used to induce the anti-idiotype (antibody 2)".

Byzantine complexity is frequently a characteristic of idiotype research and can induce in the nonspecialist a state of mind analogous to low zone tolerance. This is unfortunate because research on idiotypes leads to the central immunological dogma of Network and has contributed to many diverse areas of research, such as treatment of cancer and hormone binding to receptors. The importance of idiotypic responses in clinical medicine will also increase with the use of monoclonal antibodies for in vivo diagnosis and treatment of disease. The editors, M I Greene and A Nisonoff, can be congratulated for producing a comprehensive volume which will be the standard reference for several years. However, be warned, no effort has been made to make this volume accessible to the non-specialist.

Idiotypes were originally described as antigenic determinants present on the variable region of immunoglobulin molecules. By analogy with B cells and immunoglobulin, $T$ cells were investigated in a search for idiotypes which would define the $\mathrm{T}$ cell receptor for antigen. Unfortunately, the book predates the cloning of the $T$ cell receptor genes and the direct biochemical analysis of $\mathrm{T}$ cell receptor molecules. The last five chapters, which describe the indirect definition of the $T$ cell receptor, and those chapters exploring $T$ cell-B cell and $T$ cell- $T$ cell interaction will need to be reinterpreted using current molecular knowledge.

In summary, this is a source book for immunologists which is comprehensive but not designed for a general audience. Recent events have overtaken the chapters considering $\mathrm{T}$ cell idiotypes.

P N Goodfellow

Ectodermal dysplasias: a clinical and genetic study By N Freire-Maia and M Pinheiro. (Pp 266; figures + tables. £44.00.) New York: Alan R Liss. 1984.

Syndrome recognition presents the clinical geneticist with a problem with which any assistance is welcome. A central difficulty is in dealing with the sheer numbers of diagnostic labels. Recent developments in expert microcomputer systems offer, perhaps, the best solution but for most clinicians, for the foreseeable future, the traditional reference book is essential. For this reason the invitation to review this book by Newton Freire-Maia and Marta Pinheiro was accepted with pleasure by this reviewer. At last, a classification according to abnormalities of skin, hair, teeth, and nails, perhaps the most accessible of syndrome 'handles'.

The book begins with over 30 pages on definitions and classifications and this reader was left somewhat bemused by the further attempt to refine syndrome nomenclature; cleft lip is a malformation, for example, whereas holoprosencephaly is a monotopic paradrome!

The lists of 'ectodermal dysplasia' syndromes together with references and subject index make up the bulk of the book's 266 pages. It is obvious that the authors have been meticulous in the search of a difficult body of publications. It is this attention to detail which gives the book its value. There are, however, several aspects which deserve criticism. It requires a careful search before an explanation is found on page 26 for the subgroup numbering; 1,2 , 